\title{
Perturbation of membrane microdomains reduces mitogenic signaling and increases susceptibility to apoptosis after $\mathrm{T}$ cell receptor stimulation
}

\author{
M Nix ${ }^{1}$ and W Stoffe ${ }^{*, 1}$ \\ ${ }^{1}$ Laboratory of Molecular Neuroscience, Institute of Biochemistry, Faculty of \\ Medicine, University of Cologne, D-50931 Cologne, Germany \\ * Corresponding author: W Stoffel, Laboratory of Molecular Neuroscience, \\ Institute of Biochemistry, Faculty of Medicine, University of Cologne, Joseph- \\ Stelzmann Str. 52, D-50931 Cologne, Germany Tel: +49 221478 6881; \\ Fax: +49 221478 6882; E-mail: Wilhelm.Stoffel@uni-koeln.de
}

Received 13.10.99; revised 24.1.00; accepted 25.1.00

Edited by M Piacentini

\begin{abstract}
Acid sphingomyelinase-deficient (asmase ${ }^{-I-}$ ) mice generated by gene targeting abundantly store sphingomyelin in the reticuloendothelial system of liver, spleen, bone marrow, and in brain. Liver cells of asmase ${ }^{-I-}$ mice accumulate sphingomyelin and glycosphingolipids in purified lipid bilayers of microsomes, Golgi, and the plasma membrane, but cholesterol is depleted in the plasma membrane. Detergent-insoluble glycolipid-enriched membrane microdomains (GEM) can be isolated from hepatocytes, embryonic fibroblasts, and splenocytes of wild-type, but not of asmase $^{-I-}$ mice, by sucrose gradient density centrifugation. Lck and other Src-family kinases are reduced in isopycnic fractions of asmase ${ }^{-I-}$ splenocytes compared to GEMcontaining fractions of wild-type cells. The proliferation of asmase $^{-1-} \mathrm{T}$ lymphocytes is reduced, whereas their susceptibility to Fas-induced apoptosis is increased after $T$ cell receptor (TCR) stimulation. TNF receptor I signaling remains unimpaired. The perturbation of GEM impairs tyrosine phosphorylation and, consequently, mitogenic signaling of the TCR. Reduced MAPK activity-dependent FLICE-like inhibitory protein (FLIP) expression in asmase ${ }^{-1-}$ T lymphocytes increases their sensitivity towards Fasmediated apoptosis. Cell Death and Differentiation (2000) 7, 413-424.
\end{abstract}

Keywords: acid sphingomyelinase; membrane microdomains; caveolae; T cell receptor-induced proliferation; Fas-induced apoptosis

Abbreviations: AICD, activation-induced cell death; aSMase, acid sphingomyelinase; $\mathrm{CHX}$, cycloheximide; DISC, death-inducing signaling complex; FLIP, FLICE-like inhibitory protein; GEM, glycolipid-enriched membrane microdomains; SPM, sphingomyelin; PMA, phorbol myristoyl acetate; TNF- $\alpha$, tumor necrosis factor- $\alpha$

\section{Introduction}

The binding of MHC-peptide complexes or agonistic antibodies to the $T$ cell receptors (TCR) on mature $T$ cells initiates multiple phosphorylation of immunoreceptor-based activation motifs (ITAMs) by the Src-family protein tyrosine kinases Lck and/or Fyn. ${ }^{1}$ Subsequent recruitment of ZAP-70 kinase activates several other effector proteins, e.g. SLP-76, LAT, Shc, phosphatidylinositol-3'-kinase (PI3K), or phospholipase $\mathbf{C} \gamma(\operatorname{PLC} \gamma)$. Understanding the role of the plasma membrane in this process is still at an early stage. Two recent reports suggest the association of TCR activation with an actin-driven rearrangement of protein tyrosine kinase-rich lipid microdomains to the closest site of contact thereby forming an 'immune synapse', 2,3 The precise mechanism of this assembly process is not yet resolved. The rearrangement requires the activation of costimulatory receptors (e.g. CD28), Ras, and PI3K, by which the threshold for T cell activation is lowered and T cell proliferation is prolonged. ${ }^{4}$

TCR activation induces clonal expansion, but simultaneously sensitizes to activation-induced cell death (AICD). 5,6 The T cell surface harbors Fas (CD95), which upon binding to Fas ligand (CD95L) activates cytosolic proteases (caspases) and triggers apoptosis. ${ }^{7,8}$ Fas activates ERK transiently, but JNK permanently in a Rasdependent manner, which efficiently enhances apoptosis. ${ }^{9}$ Fas is expressed on mature $\mathrm{CD}^{+}$and $\mathrm{CD}^{+} \mathrm{T}$ cells. ${ }^{10}$ However, these $\mathrm{T}$ lymphocytes are protected from FasLinduced cell death. A candidate for the protective role is $\mathrm{Bcl}-\mathrm{X}_{\mathrm{L}}{ }^{11} \mathrm{CD} 28$ costimulation enhances $\mathrm{Bcl}-\mathrm{X}_{\mathrm{L}}$ and downregulates FasL expression. The recruitment of caspase-8 (FLICE, MACH) to the death-inducing signaling complex (DISC) at Fas is prevented by FLICE-like inhibitory protein (FLIP). ${ }^{12,13}$ The proliferatory and protective signals in the activated $\mathrm{T}$ cell fade within $48-72 \mathrm{~h}$.

The lipid bilayer of plasma membranes contains sphingomyelin (SM) and cholesterol in a rather constant ratio. $^{14}$ The two lipids mainly regulate the fluidity of the membrane. SM and cholesterol form intermolecular hydrogen bonds, cholesterol intercalates with unsaturated or trans-gauche isomerized hydrocarbon chains of fatty acids. ${ }^{15}$ Sphingolipids differ from the glycerophospholipids by functional groups prone to form hydrogen bond networks close to the lipid-water-interface. These effects stabilize an asymmetrical distribution of SM in favor of the outer leaflet of the bilayer. SM, cholesterol, and glycosphingolipids form specialized 'rafts', also termed glycolipid-enriched microdomains (GEM) or caveolae. ${ }^{16-18}$ Glycosphingolipids have an even stronger tendency than SM to separate from the glycerophospholipids. ${ }^{15}$ In melanoma cells, the membrane patches contain only $0.5 \%$ of total cellular protein, but concentrate $>90 \% \mathrm{GM} 3,>90 \%$ Ras and c-Src, and $50 \%$ 
Rho. ${ }^{19}$ They accumulate palmitoylated protein tyrosine kinases, e.g. Lck or Fyn. ${ }^{18,20}$ GEM are essential for efficient $T$ cell activation. ${ }^{21}$ Cholesterol depletion of caveolae reduces their function. A linkage between cholesterol levels and the control of cell division has been suggested. ${ }^{22}$

SM is hydrolyzed to ceramide and phosphocholine in a PLC-like reaction by acid sphingomyelinase (aSMase, EC 3.1.4.12), a lysosomal enzyme, and neutral sphingomyelinases. ASMase plays a key role in the catabolism of SM. We recently generated an aSMase-deficient mouse line that mimics the neurovisceral form (type A) of human SM storage disease, 'Niemann-Pick disease'. ${ }^{23}$ We report the impact of a dysregulated lipid metabolism on the formation of rafts and caveolae. $T$ lymphocytes isolated from asmase $^{-1-}$ mice not only scarcely proliferate after antiCD3 or anti-CD3/anti-CD28 antibody treatment, ${ }^{24}$ but also become highly susceptible to anti-Fas antibody-induced apoptosis. We suggest mechanisms by which the altered lipid composition of the plasma membrane of asmase ${ }^{-1-}$ cells associated with a perturbation of functional membrane microdomains reduces $T$ cell proliferation and sensitizes to apoptosis.

\section{Results}

\section{The lipid composition of subcellular membranes of aSMase-deficient hepatocytes is severely altered compared to wild-type hepatocytes}

We analyzed the membrane lipid composition of plasma membrane, Golgi, rough and smooth endoplasmic reticulum (ER), and mitochondria from hepatocytes of wild-type and asmase $^{-1-}$ mice. Subcellular fractions were purified by sucrose gradient density centrifugation and characterized by their respective marker enzymes and electron microscopy (data not shown). ${ }^{25}$ Lipids were extracted with chloroform/ methanol, separated by high performance thin layer chromatography (HPTLC), identified with reference lipids and by mass spectroscopy (MALDI-TOF analysis), and quantified by densitometry (Figure $1 A-D)$. The analysis revealed that $S M$ in the plasma membrane of asmase ${ }^{-1-}$ cells had accumulated to twice the concentration ( $43 \pm 6 \%$ of total phospholipids) of wild-type $(21 \pm 4 \%)$, but phosphatidylcholine (PC) and phosphatidylethanolamine (PE) were reduced from $34 \pm 2$ and $35 \pm 7 \%$ to $22 \pm 3$ and $19 \pm 1 \%$, respectively (Figure 1B). Only minor changes of the lipid composition were found in the rough ER and mitochondria, but they became significant in the smooth ER and Golgi compartment. The cholesterol concentration on the other hand was dramatically reduced in the plasma membrane of aSMase-deficient hepatocytes. The cholesterol : phospholipid ratio was about 1 in wild-type, but close to 0.5 in asmase ${ }^{-1-}$ cells (Figure 1C). Glycosphingolipids were highly accumulated in the plasma membrane of asmase ${ }^{-1-}$ cells: glucocerebrosides and ganglioside GM3 were increased twofold, and lactosylceramides eightfold, respectively (Figure 1D). ER and Golgi membranes were mainly enriched in lactosylceramide. Mitochondrial membranes were free of glycosphingolipids. The $\mathrm{N}$-linked fatty acids of SM were analyzed by mass spectrometry. No significant differences were found in chain length or degree of unsaturation in SM extracted from wild-type or asmase ${ }^{-1-}$ cells (data not shown).

Steady-state anisotropy measurements using the lipid soluble fluorescent probe diphenylhexatriene revealed that the fluidity of the membranes in aSMase-deficient cells was significantly reduced due to the altered lipid composition (Figure 1E). ${ }^{26}$ Surprisingly, this effect was smallest in the plasma membrane and most evident in the Golgi suggesting a subtle regulation of plasma membrane fluidity.

\section{Endocytotic and pinocytotic processes are not impaired in asmase ${ }^{-I-}$ embryonic fibroblasts}

To study the effect of the altered lipid composition in asmase $^{-1-}$ cells on receptor-mediated endocytosis and unspecific pinocytosis, we examined embryonic fibroblasts (EMFIs) of the two genotypes. Recombinant biotinylated human apolipoprotein E (apoE) was incorporated into PC:SM-liposomes. These liposomes were incubated with fibroblasts at $4^{\circ} \mathrm{C}$ for binding to the LDL receptor. Endocytosis was induced by raising the temperature to $37^{\circ} \mathrm{C}$. Cells were fixed and stained with streptavidin-Cy3. Wild-type and aSMase-deficient EMFIs bound and endocytosed apoEcontaining liposomes with similar efficiency (Figure 2A-D). The same observation was made with liposomes containing NBD-sphingomyelin. ${ }^{27}$ The fluorescent SM analogue at $7^{\circ} \mathrm{C}$ resided in the plasma membrane (Figure 2E,F), but at $37^{\circ} \mathrm{C}$ rapidly accumulated in lysosomes (Figure 2G,H).

\section{GEM cannot be purified from different aSMase-deficient cell types}

Membrane microdomains are formed in essentially every cell type. ${ }^{18,28}$ In some specialized cells they contain the cholesterol-binding protein caveolin, which is regarded as a structural component of caveolae and as a scaffold for several other proteins that participate in cellular signal transduction. ${ }^{18}$ We isolated the lipid rafts by sucrose gradient density centrifugation as a Triton X-100-insoluble fraction $^{19}$ from wild-type hepatocytes, EMFls, and splenocytes. GEM were visible as distinct white bands (Figure $3 A$ ). These fractions accumulated GM3 (Figure 3B) and the major part of caveolin in EMFIs, Src-family kinases and Ras (not shown) in hepatocytes, and Lck in splenocytes, respectively (Figure $3 \mathrm{C}$ ). In the respective preparations from asmase $^{-I-}$ cells, no distinct bands were visible. Rather, lipids smeared over a wide density range (Figure 3A). GM3 was spread over several fractions (Figure 3B). Negligible amounts of Src or Lck were detected in isopycnic fractions compared to wild-type GEM-containing fractions. Caveolin was only faintly stained in Western blot analysis of fractions from asmase ${ }^{-1-}$ EMFIs (Figure 3C). We immunostained EMFls of wild-type and asmase ${ }^{-1-}$ mice with anti-caveolin-2 antibody (Figure 3D,E). Asmase ${ }^{-/-}$ EMFIs were almost devoid of caveolae, whereas wild-type EMFIs showed the expected pattern. ${ }^{29}$ 


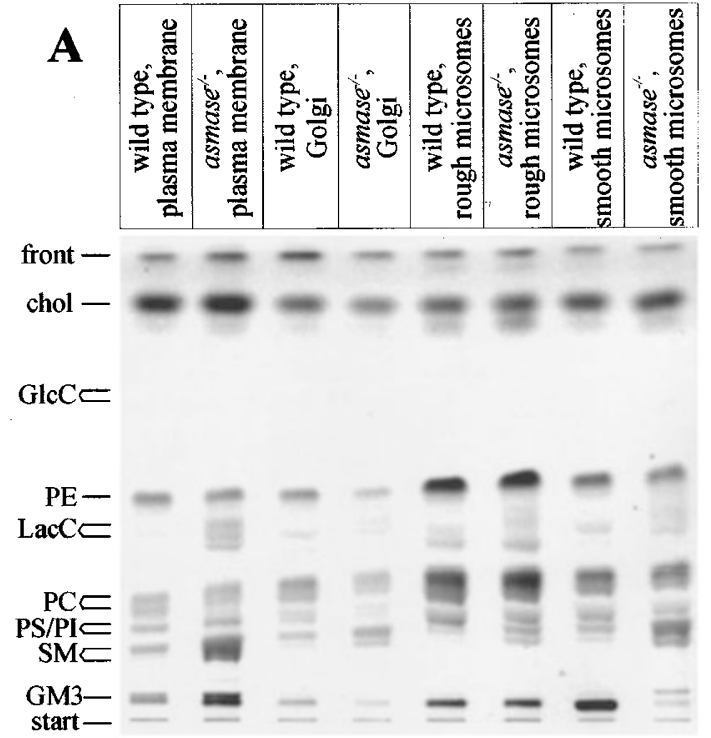

B

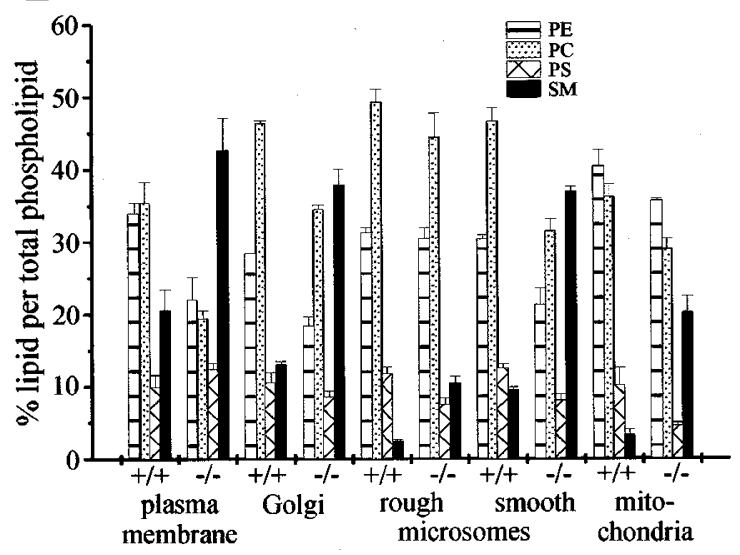

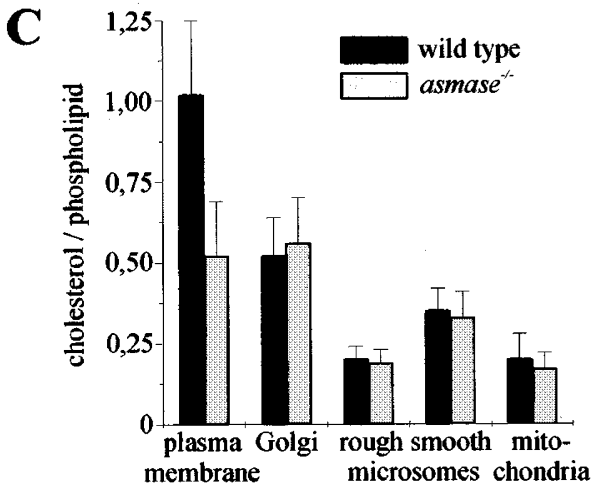

D

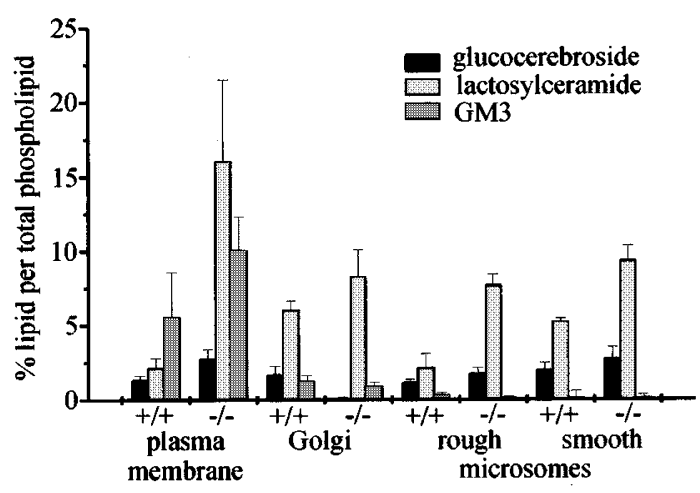

$\mathbf{E}$

\begin{tabular}{ccccc}
\hline $\begin{array}{c}\text { fluorescence } \\
\text { anisotropy }\end{array}$ & $\begin{array}{c}\text { plasma } \\
\text { membrane }\end{array}$ & Golgi & $\begin{array}{c}\text { rough } \\
\text { microsomes }\end{array}$ & $\begin{array}{c}\text { smooth } \\
\text { microsomes }\end{array}$ \\
\hline wild type & $0,196 \pm 0,007$ & $0,109 \pm 0,006$ & $0,104 \pm 0,005$ & $0,116 \pm 0,009$ \\
asmase $^{-\alpha}$ & $0,209 \pm 0,006$ & $0,167 \pm 0,009$ & $0,119 \pm 0,005$ & $0,159 \pm 0,008$ \\
\hline
\end{tabular}

Figure 1 Lipid analysis of subcellular membrane preparations. (A) Representative thin layer chromatography of lipid preparations from wild-type and asmase ${ }^{-/-}$ hepatocyte organelles. Solvent system methanol : chloroform: water $(65: 25: 4)$. Lipids were identified by standards. Chol=cholesterol, GlcC=glucocerebrosides, LacC=lactosylceramides. (B) Phospholipid composition of different liver organelles. PE (striped columns), PC (dotted), PS/PI (hatched), and sphingomyelin (black) were normalized to total phospholipid. $+/+$ and $-/-$ indicates the wild-type or aSMase-deficient genotype, respectively. (C) Cholesterol:phospholipid ratio in different organelles of liver of wild-type (solid column) and aSMase-deficient (gray) mice. (D) Comparison of the amounts of glucocerebrosides (black columns), lactosylceramides (light gray), and ganglioside GM3 (dark gray) in different organelles, each normalized to total phospholipid. Bands were analyzed by quantitative densitometry. Mean values of three different preparations. (E) Steady-state anisotropy of subcellular membrane preparations using diphenylhexatriene as a fluorescent probe. Membranes were diluted to $20 \mu \mathrm{g} / \mathrm{ml}$ protein in PBS containing $1 \mu \mathrm{g} / \mathrm{ml}$ diphenylhexatriene and fluorescence depolarization at $37^{\circ} \mathrm{C}$ was determined spectroscopically. Values are means of three experiments and inversely proportional to the fluidity of the membrane

\section{Disruption of GEM reduces tyrosine phosphorylation efficiency}

Protein tyrosine phosphorylation is one of the early events after $\mathrm{T}$ cell or growth factor receptor stimulation. ${ }^{1}$ We have shown recently that the proliferation of asmase ${ }^{-1-} \mathrm{T}$ lymphocytes is reduced after anti-CD3 and anti-CD28 stimulation compared to wild-type T cells. ${ }^{24}$ We also found a strong reduction of the number of lymphocytes in the blood of asmase $^{-1-}$ mice $(2690 \pm 175$ per microliter blood in wild-type and $1550 \pm 350$ in aSMase-deficient mice; M Nix and W Stoffel, unpublished results) which leads to the conclusion that the perturbation of GEM influences tyrosine phosphorylation efficiency and $\mathrm{T}$ cell proliferation in vitro and in vivo.

We detected tyrosine phosphorylation in wild-type T cells with anti-phosphotyrosine antibody already 2 min after stimulation with anti-CD3-PE antibody (Figure 4A). A maximum was reached after $4 \mathrm{~min}$, followed by a rapid fading within another $4 \mathrm{~min}$. In asmase as $^{-1-}$ T cells tyrosine phosphorylation was not only delayed but also dramatically reduced: only a weak tyrosine phosphorylation became visible after 6 and $8 \mathrm{~min}$, respectively.

We also detected tyrosine phosphorylated proteins after anti-CD3 and anti-CD3/anti-CD28 stimulation of 

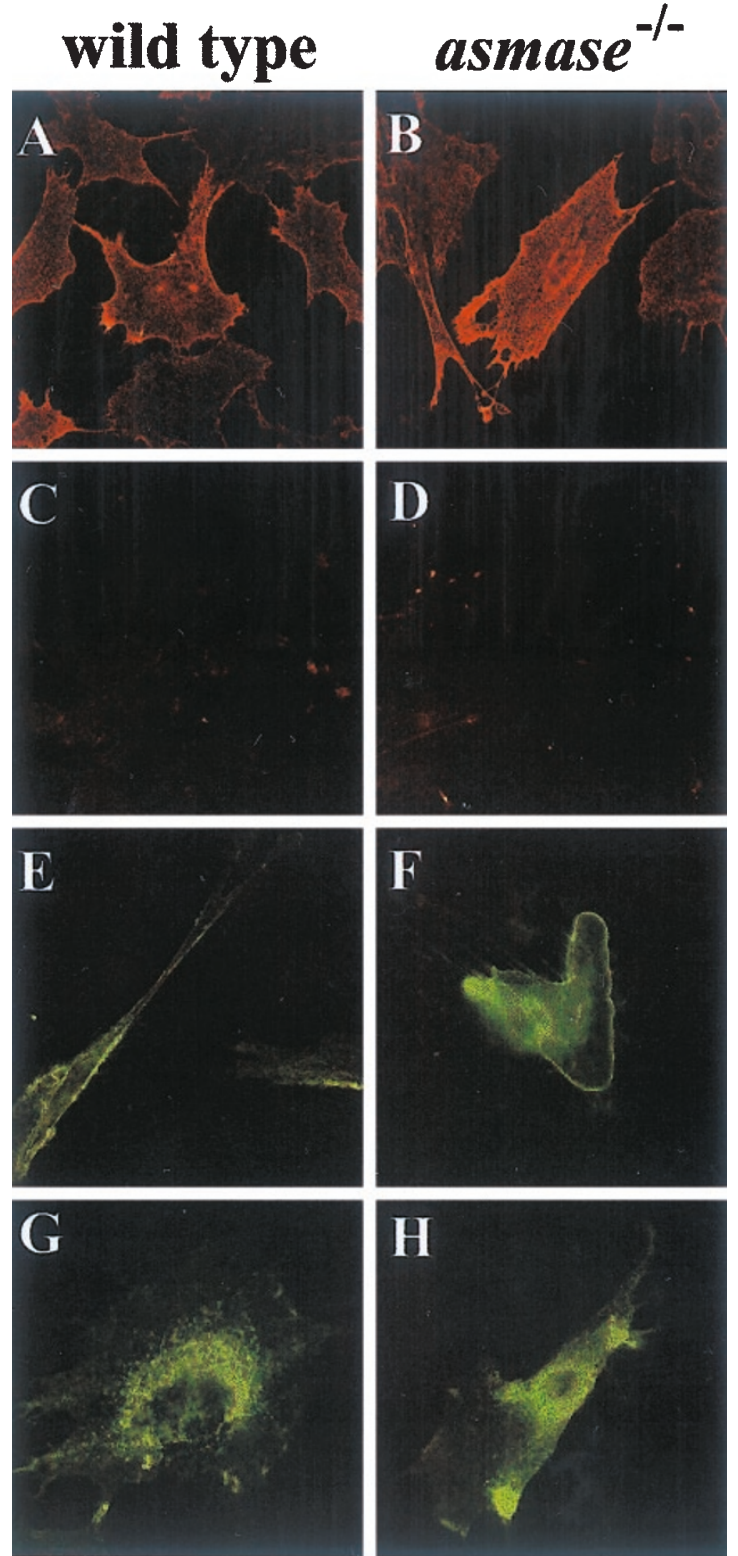

Figure 2 Endocytosis and pinocytosis are normal in asmase ${ }^{-1-}$ embryonic fibroblasts. (A-D) EMFIs (6th passage) were incubated with recombinan biotinylated apoE in PC:SM liposomes for adsorption at $4^{\circ} \mathrm{C}$. Endocytosis was initiated by warming to $37^{\circ} \mathrm{C}$ for $7.5 \mathrm{~min}$. Cells were fixed and stained with streptavidin-Cy3. (E-H) EMFIs were incubated with NBD-sphingomyelincontaining liposomes as described..$^{27}$ After warming to $37^{\circ} \mathrm{C}$ for $7.5 \mathrm{~min}$, they were washed with cold PBS and analyzed

$\mathrm{CD}^{+} \mathrm{T}$ cells by Western blotting (Figure 4B). It was again obvious that tyrosine kinase activity is significantly lower in asmase ${ }^{-1-}$ compared to wild-type lymphocytes. The kinetics after anti-CD3 stimulation were coincident with those shown in Figure 4A. This effect was smaller after anti-CD3 and anti-CD28 stimulation of the same cells: both antibodies together increased tyrosine phosphorylation efficiency both in wild-type and asmase $^{-/-} \mathrm{T}$ cells.

\section{Increased sensitivity of activated asmase ${ }^{-I-} \mathbf{T}$ lymphocytes towards anti-Fas antibody, but not TNF- $\alpha$}

TNF receptor I (TNFRI) has been described to localize to GEMs in Jurkat cells suggesting that TNFRI signaling is dependent on functional microdomains. ${ }^{30}$ Since FasL has not been found in GEM, apoptosis initiated by Fas might not require GEM-associated proteins.

We tested the effects of anti-Fas antibody and TNF- $\alpha$ on splenocytes of asmase $e^{-/-}$and wild-type mice stimulated by anti-CD3 antibody, a combination of anti-CD3 and antiCD28 antibodies, or phorbol myristoyl acetate (PMA)/ ionomycin for $36 \mathrm{~h}$. Cells were then treated with anti-Fas antibody, TNF- $\alpha$, or a combination of TNF- $\alpha$ with protein synthesis inhibitor cycloheximide $(\mathrm{CHX})$ for the time intervals indicated in Figure 5. They were stained with annexin V-FITC, DNA intercalating 7-aminoactinomycin, and anti-CD4-PE antibody for FACS analysis.

Neither wild-type nor asmase ${ }^{-1-} \mathrm{CD}^{+} \mathrm{T}$ lymphocytes pretreated with either anti-CD3 or anti-CD3/anti-CD28 showed significant apoptotic response upon TNF- $\alpha$ challenge (Figure 5A,B). When TNF- $\alpha$ and $\mathrm{CHX}$ were added, the activity of anti-apoptotic mechanisms was overcome and both cell types underwent apoptosis. $\mathrm{CHX}$ alone had no effect (not shown). Anti-CD3-stimulated asmase ${ }^{-1-}$ $\mathrm{CD}^{+} \mathrm{T}$ lymphocytes died rapidly upon challenge with anti-Fas antibody: the number of apoptotic $\mathrm{T}$ cells had doubled after $12 \mathrm{~h}$ and increased up to $70 \%$ after $24 \mathrm{~h}$, but wild-type cells barely responded after $12 \mathrm{~h}$ and became slightly apoptotic after $24 \mathrm{~h}$. When splenocytes were pretreated with $\mathrm{PMA} /$ ionomycin before stimulation with anti-Fas, TNF- $\alpha$, or TNF- $\alpha / \mathrm{CHX}$, T lymphocytes of both genotypes behaved analogously (Figure 5C). TNF- $\alpha$ again induced no apoptosis. The combination of TNF- $\alpha$ and $\mathrm{CHX}$ affected the cells more severely than after anti-CD3 or antiCD3/anti-CD28 prestimulation. Anti-Fas antibody induced significantly less apoptosis than after TCR activation.

\section{Fas expression and signaling are not altered in asmase $^{-1-}$ cells}

Fas is stored in the Golgi and rapidly transported to and exposed on the cell surface following p53 activation in vascular smooth muscle cells. ${ }^{31}$ This or other mechanisms inducing higher Fas expression might explain the strong response of asmase ${ }^{-1-} \mathrm{T}$ lymphocytes to anti-Fas. We examined this hypothesis by immunostaining intact or saponin-lysed T lymphocytes with anti-Fas-FITC. Furthermore, we compared the expression of TNF receptor I (TNFRI), transferrin receptor (CD71) and the interleukin-2 receptor $\alpha$-chain (CD25), in freshly isolated unstimulated splenocytes and after a $36 \mathrm{~h}$ stimulation with anti-CD3 or antiCD3/anti-CD28, respectively (Figure 5D). Almost all unstimulated wild-type as well as asmase ${ }^{-1-} \mathrm{CD}^{+} \mathrm{T}$ cells expressed Fas on the surface. CD71, CD25, and TNFRI expression were low on unstimulated cells. Stimulation increased the expression of the receptors in both genotypes. The levels of CD71 and CD25 were more elevated on asmase ${ }^{-1-} \mathrm{T}$ cells after stimulation than on wild-type cells. 


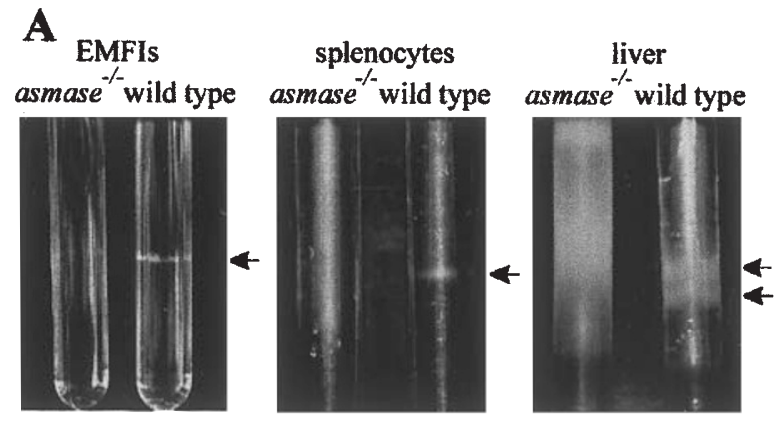

B
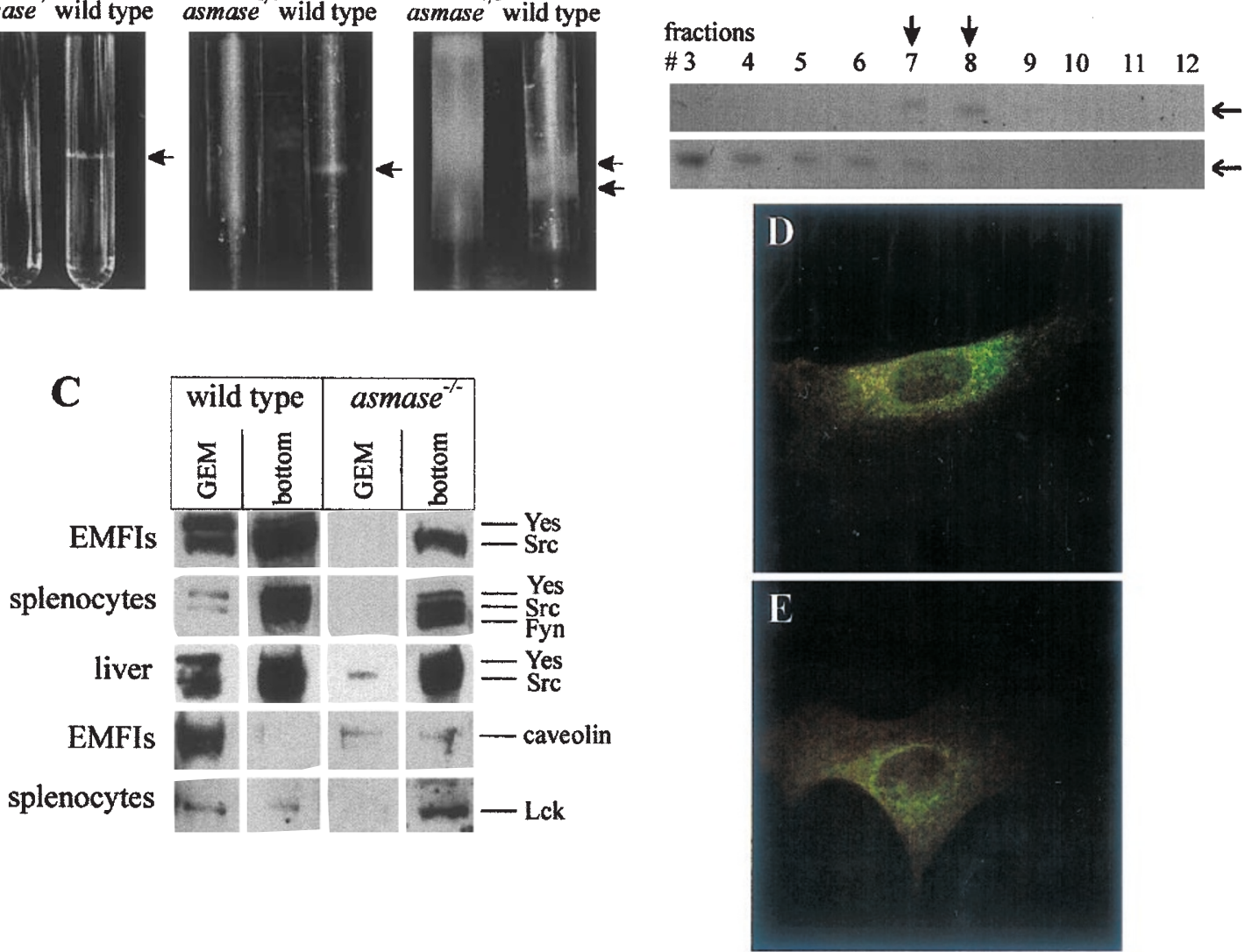

Figure 3 GEM formation is severely impaired in aSMase-deficient cells. (A) Membrane microdomains were prepared by sucrose gradient density centrifugation from EMFIs, splenocytes, and liver from wild-type and asmase ${ }^{-1-}$ mice. ${ }^{19}$ Notice the broad band of Triton X-100-insoluble lipids in asmase ${ }^{-/-}$hepatocyte fractionation. (B) Liver lipids were extracted from each fraction and separated in the solvent system $\mathrm{CHCl}_{3}: \mathrm{CH}_{3} \mathrm{OH}: \mathrm{H}_{2} \mathrm{O}: \mathrm{NH}_{3}(60: 35: 6: 2)$. Gangliosides were stained as described. ${ }^{19} \mathrm{GM} 3$ was only present in the GEM fractions of wild-type liver (upper panel, arrows), but spread over many fractions of asmase ${ }^{-1-}$ liver (lower panel). (C) Proteins of each fraction were separated by SDS-PAGE and transferred to nitrocellulose membranes. Staining for proteins that are typically associated with GEM (anti-caveolin-1, N-20; anti-c-Src, B-12; anti-Lck, MOL171) revealed partial or exclusive partitioning to GEM in wild-type cells, but hardly any partitioning in asmase ${ }^{-1-}$ cells. $^{18-20}$ Wild-type (D) and aSMase-deficient (E) EMFIs (6th passage) were fixed with methanol/acetone and stained with anticaveolin-2 antibody (N-20)

The comparable expression of Fas on wild-type and aSMase-deficient $T$ cells was confirmed by RNase protection assay (Figure 6). After integration of the signals no significant differences on the mRNA levels of caspase-8 (FLICE, MACH), Fas, and FADD after anti-CD3, anti-CD3/ anti-CD28, or $\mathrm{PMA} /$ ionomycin stimulation, respectively, were observed in the two genotypes. FasL was expressed in significantly higher amounts on asmase ${ }^{-1-} \mathrm{T}$ cells $(P<0.025$; evaluation by Student's $t$-test). However, its expression after PMA/ionomycin stimulation of lymphocytes of both genotypes was extraordinarily low. RIP was overexpressed in aSMase-deficient $\mathrm{T}$ lymphocytes only after stimulation with anti-CD3 $(P<0.025)$. Treatment of prestimulated splenocytes with a combination of anti-Fas and caspase-3 inhibitory peptide DEVD ${ }^{32}$ prevented apoptosis both in wild-type and asmase ${ }^{-1-} \mathrm{T}$ cells (Figure 7A).

\section{Mitochondrial membrane potential is intact in asmase $^{-l-}$ cells}

The breakdown of the mitochondrial membrane potential and the release of cytochrome $c$ into the cytosol has been associated with enhanced apoptosis. ${ }^{33,34}$ We tested whether the generalized lipid storage in asmase ${ }^{-/-}$cells affected the mitochondrial membrane. EMFIs (6th passage) and lymphocytes were exposed to the cationic dye rhodamine 123, which is known to selectively accumulate in intact mitochondria of living cells. ${ }^{35}$ The mitochondrial membrane potential was intact in asmase as $^{-1-}$ EMFls and in aSMase-deficient lymphocytes and remained so both in wild-type and asmase $^{-1-} \mathrm{T}$ lymphocytes even $24 \mathrm{~h}$ after treatment with anti-Fas antibody (not shown). RNase protection assay revealed an expression of $\mathrm{Bcl}-2$, Bcl-X, and Bax comparable in splenocytes of wild-type and asmase ${ }^{-1-}$ mice prestimu- 
$\mathbf{A}$
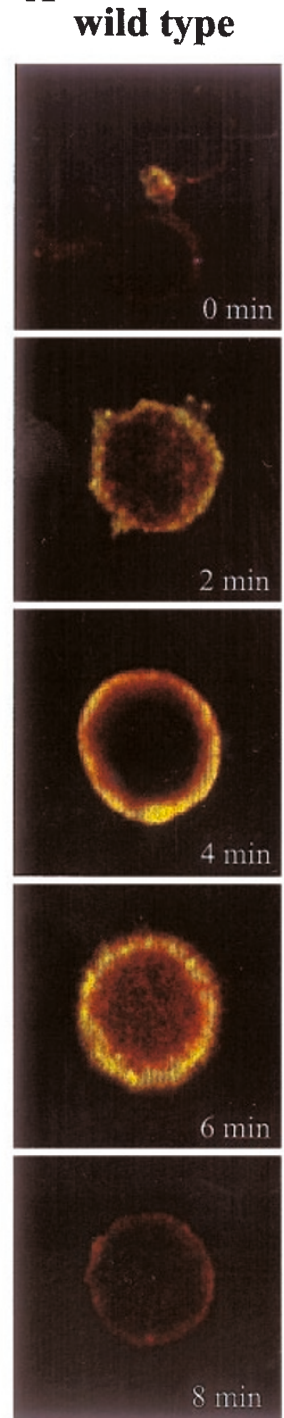

asmase $^{-x}$
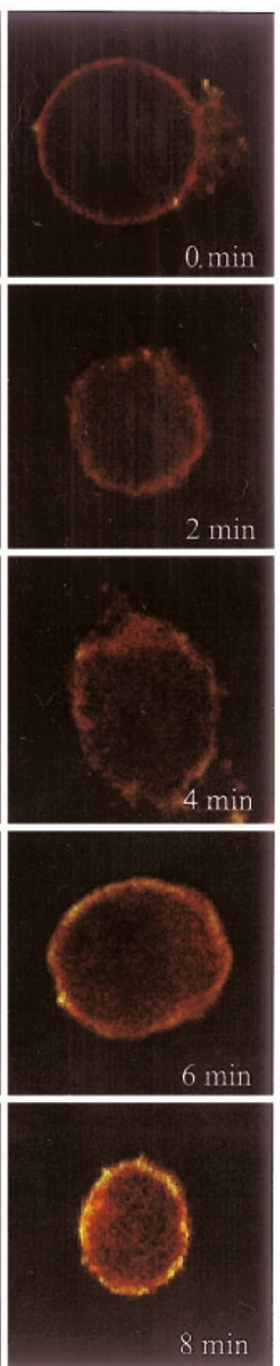

B

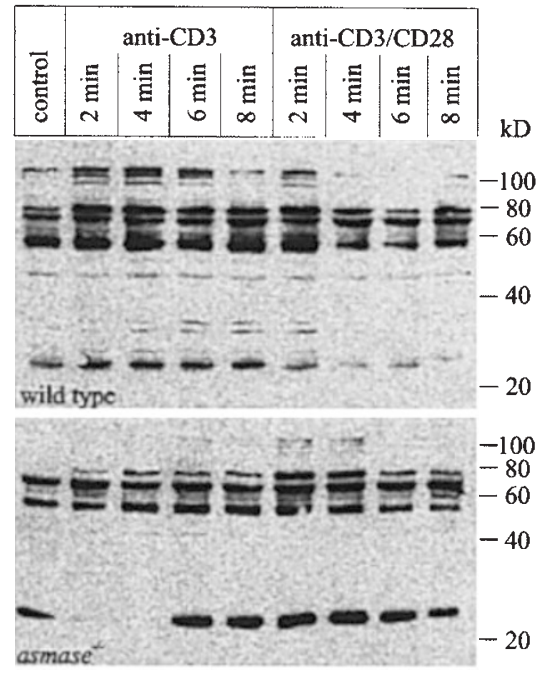

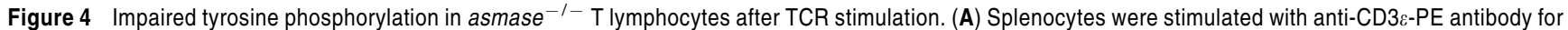
the times indicated, fixed, permeabilized, and stained with anti-phosphotyrosine antibody (PT-66). Left panel: representative wild-type; right panel: representative aSMase-deficient T lymphocytes (confocal sections). (B) CD4 ${ }^{+}$T cells were isolated by MACS, stimulated with anti-CD3 or anti-CD3/anti-CD28 antibodies for the indicated times, lysed, and equal amounts of protein subjected to polyacrylamide gel electrophoresis. Phosphotyrosine containing proteins were detected after blotting to nitrocellulose with $4 \mathrm{G} 10$ antibody

lated with anti-CD3, anti-CD3/anti-CD28, or PMA/ionomycin, respectively (Figure 6). Thus, Bcl-family proteins are not regulated differently in cells of both genotypes neither on the transcriptional nor on the protein level.

\section{Impaired TCR signaling leads to reduced expression of FLIP in asmase ${ }^{-1-}$ T lymphocytes}

Tyrosine phosphorylation was strongly impaired in asmase $^{-1-} \mathrm{T}$ cells. We traced altered signal transduction pathways by challenging splenocytes prestimulated with antiCD3 for $36 \mathrm{~h}$ with anti-Fas and $\mathrm{CHX}$, PMA, ionomycin, or wortmannin, respectively (Figure 7A,B). After anti-Fas and
$\mathrm{CHX}$ treatment, wild-type $\mathrm{CD} 4^{+} \mathrm{T}$ cells reacted as sensitive as aSMase-deficient T lymphocytes. PMA antagonized anti-Fasinitiated apoptosis in both genotypes. Wortmannin and ionomycin had no significant influence on wild-type and aSMase-deficient $\mathrm{T}$ lymphocytes compared with anti-Fas challenge alone.

TCR activation increases FLIP expression. ${ }^{36}$ However, its function as a major suppresser of AICD is discussed controversially. ${ }^{12,37}$ We examined FLIP expression in our models by quantitative RT-PCR. FLIP was expressed both in asmase $^{-1-}$ and wild-type $\mathrm{CD}^{+} \mathrm{T}$ lymphocytes to a similar extent after stimulation with PMA/ionomycin for $36 \mathrm{~h}$ (Figure 7C). After prestimulation of the same cells with anti- 
A

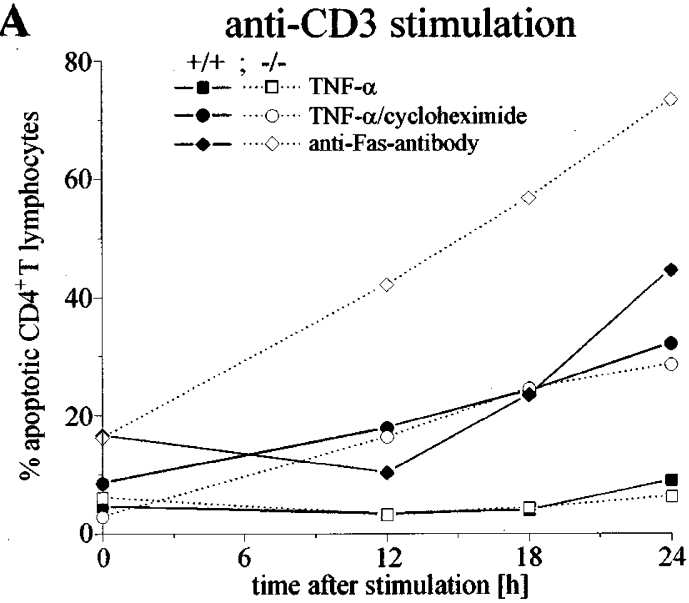

$\mathbf{C}$

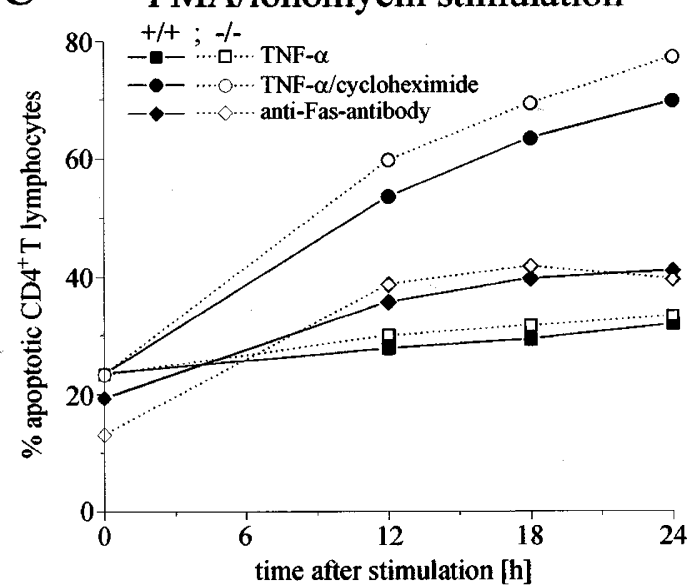

B anti-CD3/anti-CD28 stimulation

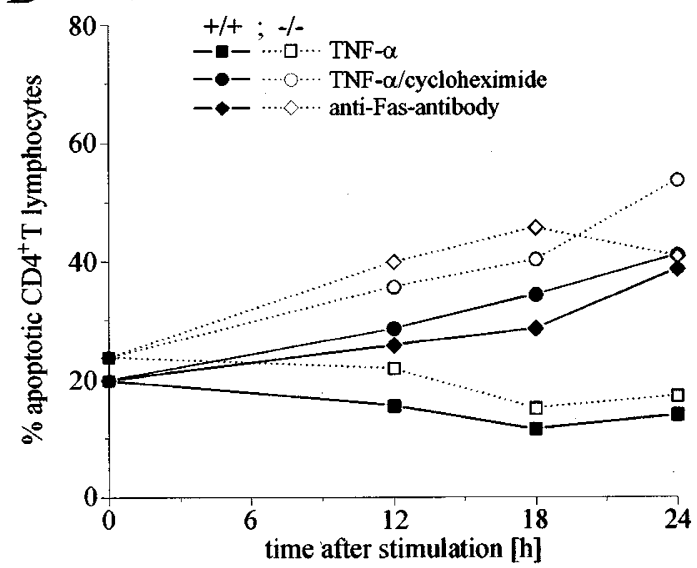

D

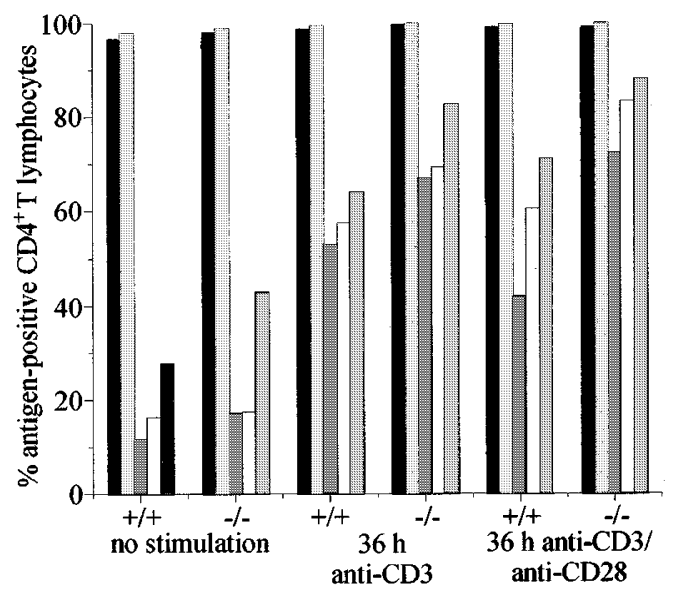

Figure 5 Apoptotic response of wild-type and asmase ${ }^{-1-} \mathrm{CD} 4^{+} \mathrm{T}$ lymphocytes to anti-Fas antibody, TNF- $\alpha$, and TNF- $\alpha / \mathrm{CHX}$ stimulation. (A) Splenocytes were grown for $36 \mathrm{~h}$ in the presence of $2 \mu \mathrm{g} / \mathrm{ml}$ anti-CD3. The medium was exchanged and cells stimulated with $200 \mathrm{ng} / \mathrm{ml} \mathrm{TNF}-\alpha(\mathbf{\square})$, TNF- $\alpha$ and $10 \mu \mathrm{g} / \mathrm{ml} \mathrm{CHX}(\mathbf{Q})$, or $5 \mu \mathrm{g} / \mathrm{ml}$ anti-Fas ( $\bullet$, respectively. After the indicated time intervals, cells were stained with 7-aminoactinomycin, annexin V-FITC, and anti-CD4-PE and analyzed by FACS. Full symbols refer to wild-type, open symbols to aSMase-deficient T cells. (B) Splenocytes were treated with anti-CD3 and $10 \mu \mathrm{g} / \mathrm{ml}$ anti-CD28. Stimulation and analyses were performed as under (A). (C) Splenocytes were grown for $36 \mathrm{~h}$ in $15 \mathrm{ng} / \mathrm{ml}$ PMA and $250 \mathrm{ng} / \mathrm{ml}$ ionomycin and challenged with cytokines and analyzed as described above. Each graph represents data from 3-6 separate experiments. (D) Splenocytes were stained with anti-CD4-PE in combination with anti-Fas-FITC (black), anti-Fas-FITC and saponin (light gray), anti-TNFRI and anti-goat-Cy2 (dark gray), anti-CD71-FITC (white), or anti-CD25FITC (gray), respectively, either immediately after preparation or after $36 \mathrm{~h}$ prestimulation with anti-CD3 or anti-CD3/anti-CD28, respectively. Shown are representatives of three independent experiments

CD3/anti-CD28 antibodies, FLIP expression was reduced to about $75 \%$ compared to wild-type cells. After anti-CD3 stimulation, FLIP expression was reduced to about $20 \%$ of wild-type level in asmase ${ }^{-1-} \mathrm{T}$ lymphocytes, which paralleled their high susceptibility to anti-Fas.

\section{Discussion}

The genetically well defined acid sphingomyelinase-deficient mouse model shows an abundant lysosomal storage of SM. ${ }^{23}$ It mimics the human Niemann-Pick disease type $A$. We describe here another facet of its molecular pathology. The lipid composition of subcellular membranes of hepatocytes is severely altered. The enrichment of SM in the membranes of the ER, of the Golgi, and in the plasma membrane of asmase $^{-1-}$ cells is accompanied by an accumulation of glucocerebrosides, lactosylceramides, and ganglioside GM3. ER and Golgi-localized neutral sphingomyelinases appear to hydrolyze SM and supply ceramide as an acceptor for glucosyl-transfer. Ceramide glycosylation in the ER contributes to the maintenance of ceramide homeostasis in the intracellular organelles. ${ }^{38}$ Although the fluidity of the intracellular membranes of asmase ${ }^{-1-}$ cells is reduced, cholesterol and ceramide levels are not significantly altered in membrane preparations of wild-type compared to aSMasedeficient cells.

Accumulation of SM and glycosphingolipids is highest in the plasma membrane of asmase ${ }^{-1-}$ cells compared to other organelles and to wild-type cells. However, plasma membrane fluidity is least altered. Hence, LDL receptor- 

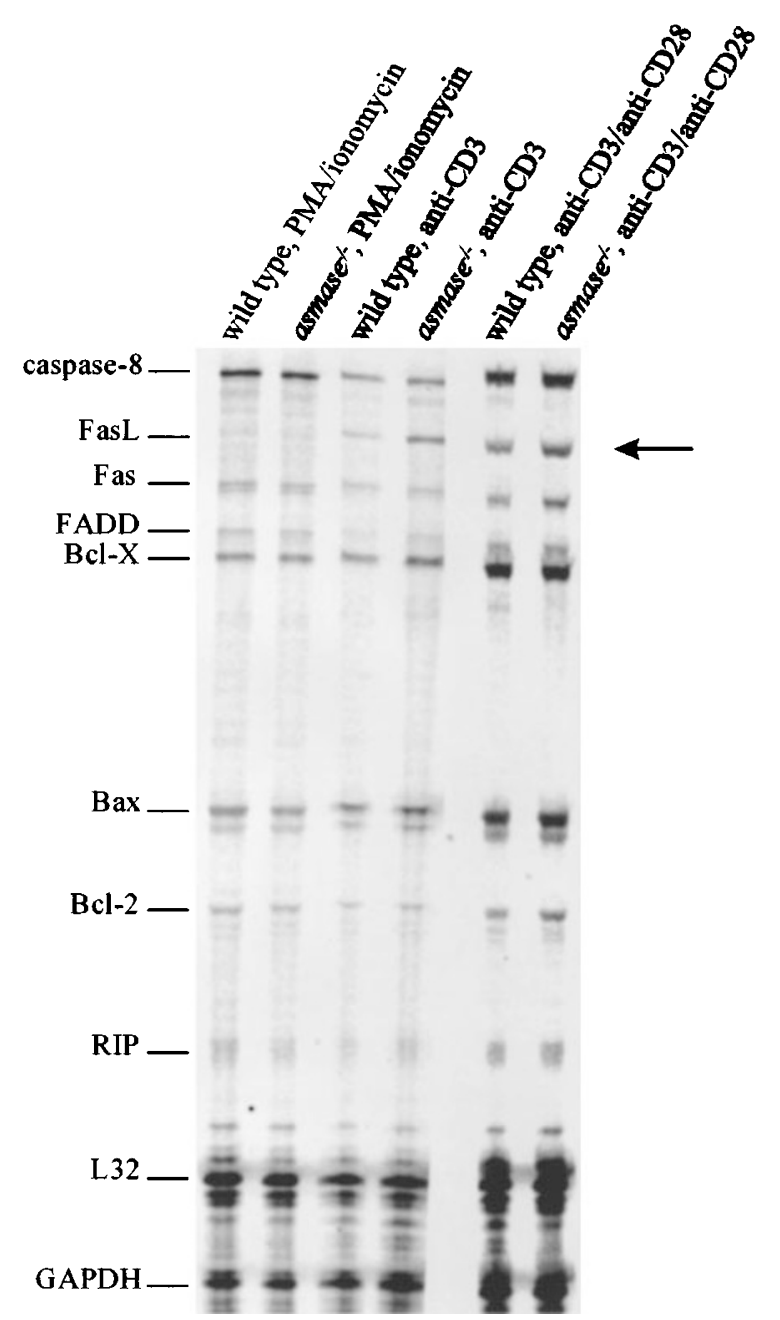

Figure 6 mRNA levels of $\mathrm{Bcl}-2$ family members or proteins contributing to Fas signaling in wild-type and asmase ${ }^{-1-}$ lymphocytes. Splenocytes were stimulated with PMA/ionomycin, anti-CD3, or anti-CD3 and anti-CD28 for $36 \mathrm{~h}$. Total RNA was isolated from $\mathrm{CD} 4^{+} \mathrm{T}$ cells and subjected to RNase protection assay. Most mRNA levels are comparable. FasL mRNA, however, is significantly elevated in anti-CD3 and anti-CD3/anti-CD28 stimulated asmase $^{-1-}$ splenocytes (arrow)

mediated endocytosis, which requires lateral diffusion of the receptor to clathrin-coated pits, ${ }^{39}$ as well as unspecific pinocytosis ${ }^{27}$ are not impaired in asmase ${ }^{-1-}$ EMFIs (Figure 2). Cholesterol is depleted in the plasma membrane of aSMase-deficient cells, whereas ceramide levels are increased sevenfold (data not shown). Due to its high affinity to SM, ${ }^{14}$ cholesterol accumulates together with SM in the lysosomes. ${ }^{23}$ This suggests a functional substitution of cholesterol by ceramide in the regulation of membrane fluidity. Both lipids induce micellar rather than lamellar lipid arrangement, decrease the transition temperature, and induce phase separation..$^{40,41}$

Ceramide generated in the ER is glucosylated and extended to higher glycosphingolipids, which are transferred to and accumulate in the plasma membrane. ${ }^{42}$ Ceramide abundantly generated in the plasma membrane is less efficiently metabolized than in the ER and accumulates as well. Due to these alterations of membrane lipid composition at an increasing age, our genetic model shows a genuine deficiency of GEM, which could be purified neither from asmase ${ }^{-1-}$ hepatocytes, EMFIs, nor from splenocytes (Figure 3A). This model is advantagous over cells or cell lines artificially depleted from cholesterol. ${ }^{22,43}$

The alterations of the biophysical properties of the plasma membrane have a strong impact on membranedependent intracellular signaling. Caveolin isoforms were not found in the plasma membrane of asmase ${ }^{-1-}$ EMFIs (Figure $3 \mathrm{C}, \mathrm{E}$ ). Apart from its role as a structural component responsible for the morphology of caveolae, caveolin is involved in the regulation of cholesterol metabolism. ${ }^{44}$ Loading cells with cholesterol inactivates the sterol response element-binding protein (SREBP), enhances cholesterol efflux to HDL and concomitantly downregulates cholesterol biosynthesis, but upregulates caveolin expression. ${ }^{45}$ Caveolin monomers are palmitoylated, oligomerize during intracellular transport to the plasma membrane, and eventually form caveolae through interaction with cholesterol. ${ }^{46}$ Thus, the reduced cholesterol content of the plasma membrane of asmase ${ }^{-1-}$ EMFIs, uncontrolled SREBP activity, and/or inefficient palmitoylation may prohibit the formation of caveolae.

GEMs are required for an optimal microenvironment for TCR signaling. We found a close association of the tyrosine kinase Lck with the GEM-containing fractions isolated from wild-type splenocytes, but in isopycnic fractions from asmase $^{-1-}$ splenocytes Lck was hardly detectable (Figure 3C). The mechanism of Lck association with GEM and its functional relevance is yet unclear. Lck and CD4 associate rapidly upon membrane insertion in the ER. ${ }^{47}$ Their co-transport to the plasma membrane follows cellular trafficking, which is inhibited by Brefeldin A. Lck targeting to the plasma membrane without interaction with CD4, but due to S-acylation of the kinase, has also been described. ${ }^{48}$ Thus, raft association might be regulated by reversible S-palmitoylation, ${ }^{49}$ whereas the presence of a myristoyl moiety at the $\mathrm{N}$-terminus mediates only a loose membrane attachment. ${ }^{50}$ The delayed, but detectable tyrosine phosphorylation (Figure 4) suggests that Lck and probably different kinases, e.g. Fyn, are attached to the plasma membrane through interaction with CD4 or TCR ITAMs, ${ }^{51}$ respectively, but due to the loss of GEM they work less efficiently. S-palmitoylation of Lck might contribute to stably connect the TCR complex and the GEM and subtly influence Lck activity.

TCR-induced IL-2 production and apoptosis have different requirements for Lck activities. ${ }^{52}$ The expression of CD71, CD25 (Figure 5D), and IL-2 ${ }^{24}$ in asmase ${ }^{-1-} \mathrm{T}$ cells upon activation and the insensitivity of Fas-induced apoptosis against ionomycin and wortmannin suggest normal activities of PI3K and PLC $\gamma$, release of $\mathrm{Ca}^{2+}$, and largely intact $\mathrm{Ca}^{2+}$-dependent signaling. ${ }^{53} \mathrm{~A}$ fusion construct consisting of the extracellular domain of CD16, the transmembrane domain of CD7 and Lck only reconstituted TCR-induced increases of intracellular $\mathrm{Ca}^{2+}$ in Lck-deficient JCam-1.6 cells. ${ }^{48}$ This again underlines the relevance of the GEM-attracting palmitoylation sites for proper signaling. 
A

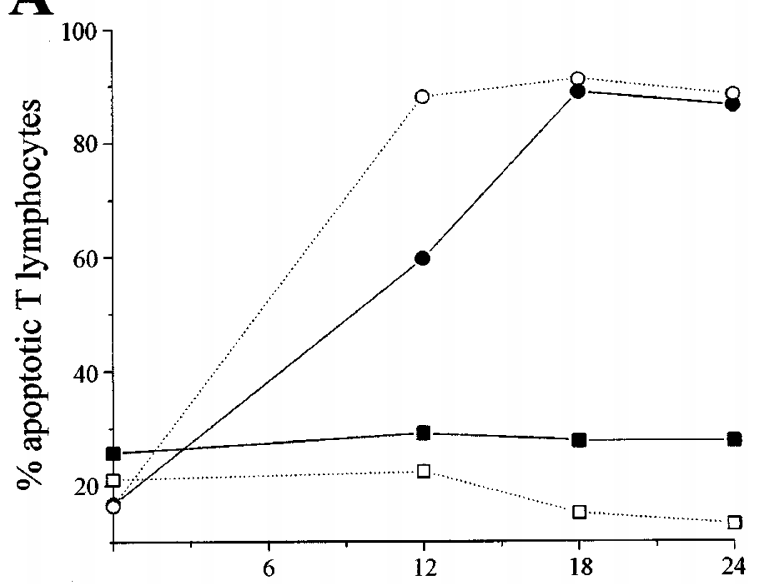

B

time after stimulation [h]
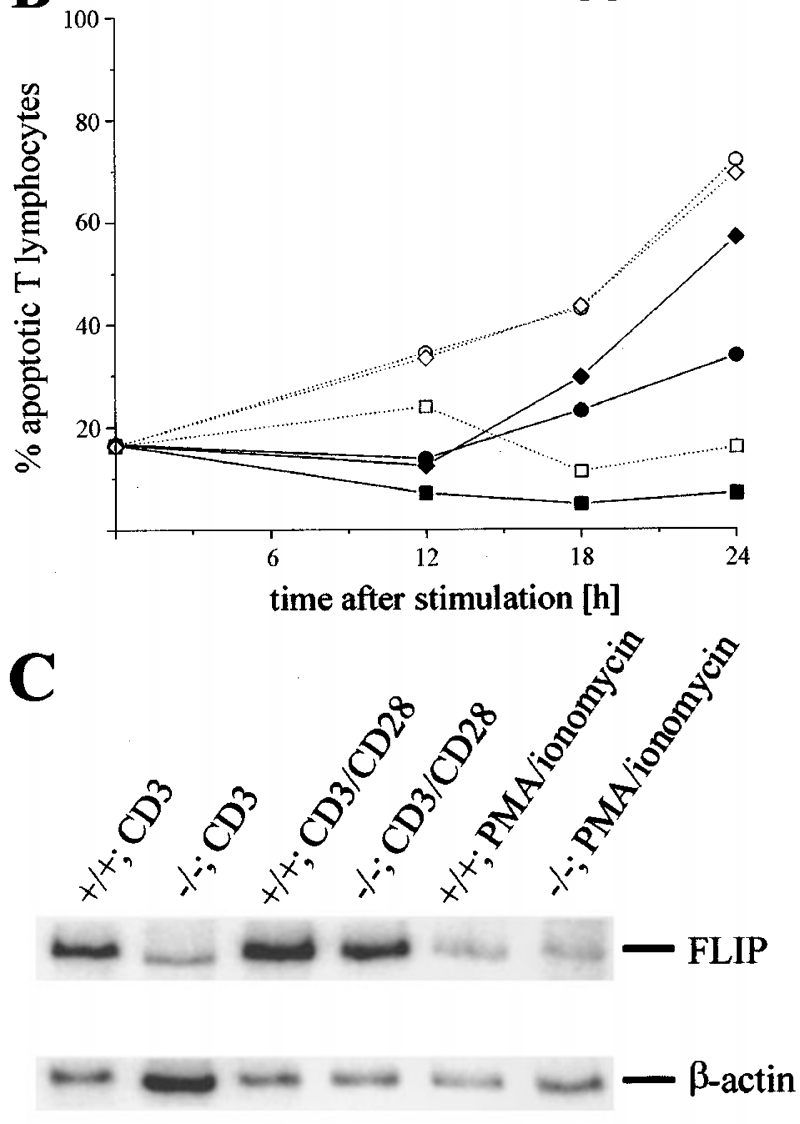

$$
\begin{array}{cccccc}
2.6 & 0.6 & 2.1 & 1.5 & 0.5 & 0.3 \\
\pm 0.3 & \pm 0.1 & \pm 0.1 & \pm 0.2 & \pm 0.4 & \pm 0.1
\end{array} \begin{gathered}
\text { FLIP: actin } \\
\text { ratio }
\end{gathered}
$$

Figure 7 Effects of different stimuli on Fas-mediated apoptosis. Splenocytes were stimulated for $36 \mathrm{~h}$ with anti-CD3 before challenge with anti-Fas in the presence of (A) $40 \mu \mathrm{g} / \mathrm{ml}$ caspase inhibitory peptide DEVD ( $\mathbf{\square}), 10 \mu \mathrm{g} / \mathrm{ml} \mathrm{CHX}$

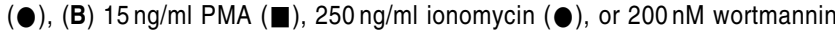
$(\bullet)$, respectively, and analyzed by FACS, as described under Figure 5. Full symbols refer to wild-type, open symbols to aSMase-deficient T lymphocytes. Each graph is representative for three independent experiments. (C) FLIP expression analyzed by radioactive RT - PCR after stimulation of wild type and asmase $^{-1-} \mathrm{CD}^{+} \mathrm{T}$ cells with anti-CD3, anti-CD3/anti-CD28, or PMA/
Asmase $^{-1-} \mathrm{T}$ cells proliferate very slowly compared to their wild-type counterparts. ${ }^{24}$ Although IL-2 is expressed at normal levels, it is stored intracellularly, but not secreted in asmase $^{-1-} \mathrm{T}$ lymphocytes. This indicates that $\mathrm{Ca}^{2+}$ release is sufficient to induce IL-2 expression, but too low to enhance vesicle fusion. ${ }^{24}$ The amplitude of TCR-induced $\mathrm{Ca}^{2+}$ mobilization is reduced in Jurkat $\mathrm{T}$ cells treated with cholesterol-depleting agents. ${ }^{21}$ Because PLC $\gamma$ activity and $\mathrm{Ca}^{2+}$ release have also been described to be dependent on functional $\mathrm{GEM}^{21}$ it may be tempting to speculate that MAPK activation and $\mathrm{Ca}^{2+}$ signaling differently depend on the dynamics of GEM reorganization.

Abnormal kinetics or sites of calcium release may also be considered to cause the elevated expression levels of CD25 on asmase ${ }^{-1-} \mathrm{T}$ cells after stimulation of the TCR (Figure 5D). Also the reduced rate of IL-2 secretion in these cells associated with perturbed feedback signals from CD25 on the surface may sustain CD25 expression.

Mimicking TCR stimulation by PMA/ionomycin, which directly activates protein kinases $C$ and bypasses GEMassociated signaling protein, ${ }^{54}$ overcomes the deficit of asmase $^{-1-} \mathrm{T}$ cells: they proliferate as fast as wild-type lymphocytes and lose their high sensitivity to Fas-induced apoptosis. Vice versa, wild-type $\mathrm{T}$ cells treated with antiFas antibody and $\mathrm{CHX}$ become as sensitive to apoptosis as asmase a $^{-1-} \mathrm{T}$ lymphocytes (Figure 7). These observations suggest that Src-family kinases are still able to phosphorylate TCR chains in asmase ${ }^{-1-} \mathrm{T}$ lymphocytes, although only to a low extent, but sufficiently to recruit PI3K and PLC $\gamma$ to the plasma membrane. However, the signal transduction cascade dependent on GEM-anchored proteins, e.g. Ras, is disrupted in GEM-deficient asmase ${ }^{-l-} \mathrm{T}$ cells resulting in reduced MAPK activation and diminished proliferation, especially if only the TCR is stimulated without co-stimulation.

Only a few effector molecules are known so far which regulate Fas-initiated apoptosis in $\mathrm{T}$ cells including FasL, FIIP, Bcl-2, and Bcl- $\mathrm{X}_{\mathrm{L}}{ }^{12,55}$ The number of FasL transcripts is elevated in asmase ${ }^{-1-} \mathrm{T}$ cells after anti-CD3 stimulation (Figure 6). The expression of FLIP, which interferes most upstream with Fas signaling, is reduced in the same cells compared to wild-type $\mathrm{T}$ lymphocytes (Figure $7 \mathrm{C}$ ). The expression of FasL and FLIP is regulated by MAPK activity. ${ }^{36,54}$ This supports the concept that impaired TCR phosphorylation mainly results in inefficient MAPK cascade activation.

$\mathrm{Bcl}-2, \mathrm{Bcl}-\mathrm{X}$, and Bax are expressed at equal levels in wild-type and asmase ${ }^{-1-}$ T lymphocytes (Figure 6) and the mitochondrial membrane potentials remain intact in both cell types even after anti-Fas antibody treatment (not shown). A different transcriptional or (post)translational

ionomycin, respectively, for $36 \mathrm{~h} .2 \mu \mathrm{g}$ of total RNA were used for cDNA synthesis. $1 / 10$ of the cDNA was then amplified by PCR with primers specific for $\mathrm{mFLIP}$ or $\beta$-actin, respectively. Aliquots of the PCR products were resolved on a $5 \%$ SDS-polyacrylamide gel. Bands were quantified using ImageQuaNT. FLIP expression was normalized to $\beta$-actin expression and shown as mean value \pm mean deviation of three independent experiments 
regulation of $\mathrm{Bcl}$-family proteins may therefore be excluded to contribute to the increased sensitivity of asmase ${ }^{-1-} \mathrm{T}$ cells to apoptosis. The alteration of membrane lipid composition neither influenced expression levels of components of the pro-apoptotic signaling cascade, e.g. Fas, FADD, RIP, and caspase-8 (Figure 6), nor the p53mediated expression of Fas on the cell surface. ${ }^{31}$

No difference is observed in the apoptotic response to TNF- $\alpha$ and TNF- $\alpha$ in combinations with $\mathrm{CHX}$ in asmase ${ }^{-1-}$ and wild-type $\mathrm{T}$ lymphocytes. This suggests that TNFRI signaling is not coupled to TCR activation and confirms that TNFRI directly activates the MAPK ERK via TRAF2 and NIK. ${ }^{56}$ The influence of GEM on the well-defined proteinprotein interactions on the TNF receptor may be considered very unlikely. ${ }^{30,57}$

Sphingolipids, glycosphingolipids, and cholesterol thermodynamically favor to separate from glycerophospholipids by forming dynamic 'rafts' in the plain of the lipid bilayer. Fatty acylated proteins partition into the microdomains. We suggest that alterations of the lipid composition, especially cholesterol depletion, of the plasma membrane of asmase $^{-1-}$ cells disturbs the thermodynamic equilibrium and interferes with the formation of GEM. Our mouse model allows the dissection of signaling cascades which are either dependent on or largely independent from GEM. The activation of the MAPK cascade is dependent on several acylated proteins, e.g. Lck and Ras, which are integrated into the membrane microdomains. MAPK cascade initiation is therefore severely impaired after TCR activation in asmase $^{-1-} \mathrm{T}$ cells which causes their high sensitivity to Fas-induced apoptosis. On the other hand, signaling proteins that only transiently adhere to the plasma membrane, e.g. PI3K or PLC $\gamma$, remain functionally unimpaired in asmase ${ }^{-1-}$ cells. In order to generate a coherent picture of the proximal events of TCR ligation a method for the purification of the TCR complex associated with GEM will have to be established which circumvents physical interventions that alter the molecular composition of GEM.

\section{Materials and Methods}

\section{Lipid extraction and analysis}

Subcellular membranes of liver cells of wild-type and asmase ${ }^{-1-}$ mice $(n=5 ; \text { CD57BL/ } 6 \times 129 / 01 a)^{23}$ were prepared and the purity of the fractions was controlled by marker enzyme assays and electron microscopy. ${ }^{25}$ Lipids were extracted with chloroform : methanol $1: 2(\mathrm{v} /$ v) and total lipids were separated by high performance thin layer chromatography (HPTLC) in the solvent system chloroform/methanol/ water $(65: 25: 4)$, cholesterol and ceramide in chloroform/methanol (15:1), and gangliosides in chloroform/methanol/0.2\% $\mathrm{CaCl}_{2}$ $(60: 40: 9)$. Lipids were charred with $50 \%$ sulfuric acid, plates were scanned and quantified with ImageQuaNT ${ }^{\mathrm{TM}}$ software. Lipid bands were identified using lipid standards. Their structure was verified and analyzed by MALDI-TOF analysis.

Steady-state anisotropy measurements were carried out as described. ${ }^{26}$ In brief, membranes were suspended at $20 \mu \mathrm{g} / \mathrm{ml}$ protein in PBS. Fluorescence depolarization of diphenylhexatriene $(1 \mu \mathrm{g} / \mathrm{ml})$ was determined spectroscopically at $37^{\circ} \mathrm{C}$ using a Perkin Elmer LS50B luminiscence spectrometer.

\section{Cell culture}

Splenocytes were prepared from 4-6-months-old mice, plated at a density of $2 \times 10^{6}$ cells $/ \mathrm{ml}$ and cultured in RPMI 1640 medium supplemented with $10 \% \mathrm{FCS}, 100 \mu \mathrm{g} / \mathrm{ml}$ penicillin/streptomycin, $1 \mathrm{mM}$ sodium pyruvate, $0.03 \%$ glutamine, $50 \mu \mathrm{M}$ mercapoethanol, and nonessential amino acids at $37^{\circ} \mathrm{C}$ in a humidified incubator under $5 \% \mathrm{CO}_{2}$. They were stimulated for $36 \mathrm{~h}$ with (a) $2 \mu \mathrm{g} / \mathrm{ml}$ anti-CD3 $\varepsilon$-antibody (145-2C11, PharMingen), (b) anti-CD3 $\varepsilon$ antibody together with $10 \mu \mathrm{g} /$ $\mathrm{ml}$ anti-CD28 antibody (37.51, PharMingen), or (c) $15 \mathrm{ng} / \mathrm{ml}$ phorbol myristoyl acetate (Sigma) and $250 \mathrm{ng} / \mathrm{ml}$ ionomycin (Sigma), respectively. Five $\mu \mathrm{g} / \mathrm{ml}$ anti-FasL antibody (MFL3, PharMingen) was added to each incubation mixture. Primary embryonic fibroblasts were grown in DMEM supplemented with $10 \% \mathrm{FCS}, 100 \mu \mathrm{g} / \mathrm{ml}$ penicillin/ streptomycin, and $0.03 \%$ glutamine.

\section{Analysis of endocytosis and pinocytosis}

Liposomes were prepared by ultrasonication from purified soybean lecithin and sphingomyelin or NBD-sphingomyelin $(9: 1),{ }^{27}$ respectively. Recombinant human apolipoprotein $\mathrm{E}(\mathrm{apoE})$ was biotinylated with Biotin-BMCC (Pierce) and dialyzed overnight against PBS. Biotinylated apoE was added to PC:SM-liposomes and extruded 15 times through two-stacked $100 \mathrm{~nm}$ filters using a LiposoFast extruder (Avestin). Liposomes were adsorbed to embryonic fibroblasts (6th passage) at $4^{\circ} \mathrm{C}$ for $1 \mathrm{~h}$. Endocytosis was started by raising the temperature to $37^{\circ} \mathrm{C}$. Cells were washed at the indicated times with cold PBS, and fixed with $4 \%$ paraformaldehyde in PBS. ApoEcontaining liposomes on the surface of the cells were stained with $1 \mu \mathrm{g} / \mathrm{ml}$ streptavidin-Cy3 (Sigma) for $1 \mathrm{~h}$ in $20 \mathrm{mM}$ Tris $\mathrm{pH} \mathrm{7.5,}$ $150 \mathrm{mM} \mathrm{NaCl}, 1 \% \mathrm{BSA}$. Liposomes containing NBD-SM were washed with cold PBS after the respective incubation time at $37^{\circ} \mathrm{C}$ and stored on ice until analyzed. An immersion objective of the Zeiss Axioskop (magnification: $400 \times$ ) was used for fluorescence microscopy.

\section{Isolation of GEM}

Membrane microdomains were prepared from liver (about $400 \mathrm{mg}$ wet weight), splenocytes $\left(2 \times 10^{8}\right)$, and EMFIs $\left(4 \times 10^{7}\right)$ from wild type and asmase $^{-1-}$ mice, respectively, by sucrose gradient density centrifugation. ${ }^{19}$ One $\mathrm{ml}$ fractions were collected and the protein content was determined after dialysis (BCA Kit, Pierce). Gangliosides were extracted and analyzed as described. ${ }^{19}$

\section{Western blots}

Proteins of each fraction were separated by SDS-PAGE on $12 \%$ gels and transferred to nitrocellulose membranes. ${ }^{19}$ The membrane was incubated with the primary antibody in the appropriate dilution (anticaveolin-1, N-20, St. Cruz; anti-c-Src, B-12, St. Cruz; anti-H-Ras, 259, St. Cruz; anti-Lck, MOL171, PharMingen) followed by the respective anti-IgG antibody conjugated with horseradish peroxidase (Sigma) and developed with LumiLight Western blotting substrate (Roche).

$\mathrm{CD}^{+}{ }^{+} \mathrm{T}$ cells were isolated by MACS using anti-CD4 antibody labeled with magnetic beads (Miltenyi Biotech), stimulated with antiCD3 or anti-CD3 plus anti-CD28 antibodies for the times indicated and lysed in cold lysis buffer $(20 \mathrm{mM}$ Tris $\mathrm{pH} 7.4,140 \mathrm{mM} \mathrm{NaCl}, 1 \mathrm{mM}$ EDTA, $1 \mathrm{mM}$ EGTA, $10 \mathrm{mM} \mathrm{NaF}, 10 \mathrm{mM} \mathrm{Na}{ }_{4} \mathrm{P}_{2} \mathrm{O}_{7}, 1 \mathrm{mM} \mathrm{Na} \mathrm{VO}_{4}$, $1 \%$ Triton $\mathrm{X}-100$, Complete $^{\mathrm{TM}}$ protease inhibitor [Roche]). Equal amounts of protein were loaded onto a $12 \%$ polyacrylamide gel, blotted to nitrocellulose and probed with an anti-phosphotyrosine antibody (4G10, Upstate) and an anti-mouse IgG-peroxidase conjugate as described above. 


\section{Immunocytochemistry}

Embryonic fibroblasts (6th passage) were washed with PBS and fixed with cold methanol/acetone $(1: 1)$ for $10 \mathrm{~min}$. They were stained with $2 \mu \mathrm{g} / \mathrm{ml}$ anti-caveolin 2 antibody ( $\mathrm{N}-20$, St. Cruz) and $0.5 \mu \mathrm{g} / \mathrm{ml}$ antigoat-Cy2 (Jackson) for $1 \mathrm{~h}$ in $\mathrm{PBS} / 3 \% \mathrm{BSA} / 0.1 \%$ saponin each. Pictures were taken using a Zeiss Axioskop equipped with a Hamamatsu C4742-95 digital camera and an appropriate filter setting (magnification: $1000 \times$ ).

For tyrosine phosphorylation analysis, $10^{6}$ splenocytes in $200 \mu \mathrm{l}$ medium were stimulated with $10 \mu \mathrm{g} / \mathrm{ml}$ anti-CD3 $\varepsilon-P E$ for $0,2,4,6$, and $8 \mathrm{~min}$. Cells were sedimented, resuspended in PBS and fixed in $2 \%$ paraformaldehyde in PBS for $15 \mathrm{~min}$. They were spun down on slides, permeabilized with $0.5 \%$ saponin in PBS, and stained with $20 \mu \mathrm{g} / \mathrm{ml}$ anti-phosphotyrosine antibody (PT-66, Sigma) and $0.5 \mu \mathrm{g} / \mathrm{ml}$ antimouse-Cy2 (Jackson). Confocal sections were taken with a Leica DM Irbe/TCS SP microscope (magnification: $1600 \times$ ).

\section{FACS analyses}

Splenocytes $\left(10^{6}\right.$ cells $\left./ \mathrm{ml}\right)$ were plated in 24-well plates and challenged for 12, 18, and $24 \mathrm{~h}$ with (a) $200 \mathrm{ng} / \mathrm{ml} \mathrm{hTNF- \alpha}$ $\left(6.6 \times 10^{6} \mathrm{U} / \mathrm{mg}\right.$, BASF-Knoll), (b) hTNF- $\alpha$ in combination with $10 \mu \mathrm{g} /$ $\mathrm{ml} \mathrm{CHX} \mathrm{(Sigma),} \mathrm{(c)} 2 \mu \mathrm{g} / \mathrm{ml}$ anti-Fas antibody (Jo-2, PharMingen), (d) anti-Fas antibody together with either CHX, PMA, ionomycin, $40 \mu \mathrm{g} / \mathrm{ml}$ DEVD-FMK (Calbiochem), or $200 \mathrm{nM}$ wortmannin (Sigma). Cells were sedimented at $320 \times g$ and $4^{\circ} \mathrm{C}$ for $5 \mathrm{~min}$ and resuspended in PBS containing $1 \% \mathrm{BSA}, 20 \mu \mathrm{g} / \mathrm{ml}$ 7-aminoactinomycin (Sigma), and $1 \mu \mathrm{g} /$ $\mathrm{ml}$ anti-CD4-PE antibody (GK1.5, PharMingen), then incubated on ice for $20 \mathrm{~min}$. One $\mathrm{ml}$ staining buffer (10 mM HEPES pH 7.4, $150 \mathrm{mM}$ $\mathrm{NaCl}, 5 \mathrm{mM} \mathrm{KCl}, 1 \mathrm{mM} \mathrm{MgCl}$, $1.8 \mathrm{mM} \mathrm{CaCl}_{2}$ ) was added. Samples were centrifuged as above, pellets resuspended in staining buffer containing $10 \mathrm{ng} / \mathrm{ml}$ annexin V-FITC conjugate (Alexis) and incubated for $15 \mathrm{~min}$ at room temperature. After dilution with an equal amount of staining buffer, samples were stored on ice until analyzed on a FACScan (CELLQuest software, Becton Dickinson). For receptor surface expression analysis, splenocytes were fixed in $2 \%$ paraformaldehyde in PBS for 20 min. Staining was performed with $30 \mu \mathrm{g} / \mathrm{ml}$ anti-CD4-PE in the presence of $10 \mu \mathrm{g} / \mathrm{ml}$ anti-Fas-FITC (Jo2, PharMingen), $5 \mu \mathrm{g} / \mathrm{ml}$ anti-CD71-FITC (C2, PharMingen), $5 \mu \mathrm{g} / \mathrm{ml}$ antiCD25-FITC (7D4, PharMingen), or $20 \mu \mathrm{g} / \mathrm{ml}$ anti-TNFRI (G-20, St. Cruz) and $20 \mu \mathrm{g} / \mathrm{ml}$ anti-goat-Cy2 (Jackson), respectively, in PBS/ $0.5 \% \mathrm{BSA}$ for $30 \mathrm{~min}$. Cells were permeabilized for intracellular staining of Fas with $0.5 \%$ saponin in the staining solution. After brief centrifugation and one wash, cells were resuspended in PBS/BSA and analyzed by FACS.

\section{Monitoring of mitochondrial membrane potential}

Splenocytes or fibroblasts were incubated with $10 \mu \mathrm{g} / \mathrm{ml}$ rhodamine 123 (Sigma) in the respective medium, then incubated for $30 \mathrm{~min}$ at $37^{\circ} \mathrm{C}$. Cells were washed twice with PBS and resuspended in PBS for analysis.

\section{RNA analyses}

$\mathrm{CD}^{+} \mathrm{T}$ cells were isolated after stimulation by MACS as described above. RNA was extracted by the Trizol method (Sigma). RNase protection assay was performed according to the manufacturer's instructions (PharMingen). For quantitation of FLIP mRNA, $2 \mu \mathrm{g}$ of total RNA were used for CDNA synthesis with hexanucleotide primers. $1 / 10$ of the synthesized cDNA was amplified by PCR using $\left[{ }^{32} \mathrm{P}\right] \mathrm{dCTP}$ and the primers $5^{\prime}$-TCTGCCGAGGTCATTCACCAGGTGG-3' and 5'-
GACTGGGTGTACTTCTGGATCTTTGT-3'. After 21 cycles, the reaction was stopped and the products were analyzed on a $5 \%$ SDS-polyacrylamide gel.

\section{Acknowledgements}

We thank B Jenke for her excellent technical assistance and $P$ Bauer for her kind help with FACS analyses. This work was supported by the Deutsche Forschungsgemeinschaft SFB 243, Project A4, and by the Federal Ministry for Education, Science, Research and Technology 01 KS9502 (Center for Molecular Medicine Cologne, ZMMK), Project 24.

\section{References}

1. Wange RL and Samelson SE (1996) Signaling at the TCR. Immunity 5: 197-205

2. Wülfing $C$ and Davis MM (1998) A receptor/cytoskeletal movement triggered by costimulation during T cell activation. Science 282: 2266-2269

3. Viola A, Schroeder S, Sakakibara Y and Lanzaveccia A (1999) T lymphocyte costimulation mediated by reorganization of membrane microdomains. Science 283: $680-682$

4. Rudd CE (1997) Upstream-downstream: CD28 cosignaling pathways and T cell function. Immunity 4: 527-534

5. Ju ST, Panka DJ, Cui H, Ettinger R, E-Khatbl M, Sherr DH, Stanger BZ and Marshack-Rothstein A (1995) Fas (CD95)/Fas ligand interactions required for programmed cell death after T cell activation. Nature 373: 444-448

6. Dhein J, WalczakH, Bäumler C, Debatin KMand KrammerPH (1995) Autocrine T cell suicide mediated by APO-1 (Fas, CD95). Nature 373: 438-441

7. Nicolson DW and Thornberry NA (1997) Caspases: killer proteases. Trends Biochem. Sci. 22: 299-306

8. Villa P, Kaufmann SH and Earnshaw WC (1997) Caspases and caspase inhibitors. Trends Biochem. Sci. 22: 388-393

9. GoillotE, Raingeaud J, Rangers A, Tepper RI, Davis RJ, Harlow E and Sanchez I (1997) Mitogen-activated protein kinase-mediated Fas apoptotic signaling pathway. Proc. Natl. Acad. Sci. 94: 3302-3307

10. Mariani SM, Matiba B and KrammerPH(1996). CD95 (APO-1/Fas) and its ligand in the mouse immune system. Behring Inst. Mitt. 97: 12-23

11. Boussiotis VA, Lee BJ, Freeman GJ, Gribben JG and Nadler LM (1997) Induction of $T$ cell clonal anergy results in resistance, whereas CD28-mediated costimulation primes for susceptibility to Fas- and Bax-mediated programmed cell death. J. Immunol. 159: 3156-3167

12. Irmler M, Thome M, Hahne M, Schneider P, Hoffmann K, Steiner V, Bodmer JL, Schröter M, Burns K, Mattmann C, Rimoldi D, French LE and Tschopp J (1997) Inhibition of death receptor signals by cellular FLIP. Nature 388: 190-195

13. Peter ME, Kischkel FC, Scheuerpflug CG, Medema JP, Debatin KM and Krammer PH (1997) Resistance of cultured peripheral T cells towards activationinduced cell death involves lack of recruitment of FLICE (MACH/caspase-8) to CD95 death-inducing signaling complex. Eur. J. Immunol. 27: 1207-1212

14. Sankaram MB and Thompson TE (1990) Interaction of cholesterol with various glycerophospholipids and sphingomyelin. Biochemistry 29: 10670-10675

15. Chapman D and Benga $G$ (1984) Biomembrane fluidity - studies of model and natural biomembranes. In: Chapman D, (ed) Biological Membranes, Vol. 5. Academic Press: London, pp. 1-56

16. Zhang W, Trible RP and Samelson LE (1998) LAT palmitoylation: its essential role in membrane microdomain targeting and tyrosine phosphorylation during $T$ cell activation. Immunity 9: 239-246

17. Moran M and Miceli MC (1998) Engagement of GPI-linked CD48 contributes to TCR signals and cytoskeletal reorganization: a role for lipid rafts in cell activation. Immunity 9: 787-796

18. Shaul PW and Anderson RGW (1998) Role of plasmalemmal caveolae in signal transduction. Am. J. Physiol. 275: L843-L851

19. Hakomori S, Yamamura S and Handa K (1998) Signal transduction through glyco(sphingo)lipids. Ann. N. Y. Acad. Sci. 845: 1-10

20. Koegl M, Zlatkine P, Ley SC, Courtneidge SA and Magee Al (1994) Palmitoylation of multiple Src-family kinases at a homologous $\mathrm{N}$-terminal motif. Biochem. J. 303: 749-753

21. Xavier R, Brennan T, Li Q, McCormack C and Seed B (1998) Membrane compartmentalization is required for efficient $\mathrm{T}$ cell activation. Immunity 8: 723732 
22. Furuchi T and Anderson RGW (1998) Cholesterol depletion of caveolae causes hyperactivation of extracellular signal-related kinase (ERK). J. Biol. Chem. 273 21099-21104

23. Otterbach B and Stoffel W (1995) Acid sphingomyelinase-deficient mice mimic the neurovisceral form of human lysosomal storage disease (Niemann-Pick disease). Cell 81: 1053-1061

24. Stoffel B, Bauer P, Nix M, Deres K and Stoffel W (1998) Ceramide-independent CD28 and TCR signaling but reduced IL-2 secretion in T cells of acid sphingomyelinase-deficient mice. Eur. J. Immunol. 28: 874-880

25. Fleischer S and Kervina M (1974) Subcellular fractionation of rat liver. Methods Enzymol. 31: 6-41

26. Koike T, Ishida G, Tanigushi M, HigakiK, AyakiY, Saito M, Sakakihara Y, Iwamor M and Ohno K (1998) Decreased membrane fluidity and unsatturated fatty acids in Niemann-Pick disease type C fibroblasts. Biochim. Biophys. Acta. 1406 $327-335$

27. Koval Mand Pagano RE (1990) Sorting of an internalized plasma membrane lipid between recycling and degradative pathways in normal and Niemann-Pick, type A fibroblasts. J. Cell Biol. 111: 429-42

28. Brown DA and London $E$ (1998) Functions of lipid rafts in biological membranes. Annu. Rev. Cell. Dev. Biol. 14: 111-136

29. Scherer PE, Okamoto T, Chun M, Nishimoto L, Lodish HF and Lisanti MP (1996) Identification, sequence, and expression of caveolin-2 defines a caveolin gene family. Proc. Natl. Acad. Sci. 93: 131-135

30. Ko YG, Lee JS, Kang YS, Ahn JH and Seo JS (1999) TNF- $\alpha$-mediated apoptosis is initiated in caveolae-like domains. J. Immunol. 162: 7217-7223

31. Bennett M, Macdonald K, Chan SW, Luzio JP, Simari R and Weissberg P (1998) Cell surface trafficking of Fas: a rapid mechanism of p53-mediated apoptosis. Science 282: 290-293

32. Talanian RV, Quinlan C, Trautz S, Hackett MC, Mankovich JA, Banach D, Ghayur T, Brady KD and Wong WD (1997) Substrate specificities of caspase family proteases. J. Biol. Chem. 272: 9677-9682

33. Yang J, LiuX, Bhalla K, Kim CN, Ibrado AM, Cai J, Peng TI, Jones DP and Wang X (1997) Prevention of apoptosis by Bcl-2: release of cytochrome C from mitochondria blocked. Science 275: 1129-1132

34. Kluck RM, Bossy-Wetzel E, Green DR and Newmeyer DD (1997) The release of cytochrome $\mathrm{C}$ from mitochondria: a primary site for $\mathrm{Bcl}-2$ regulation of apoptosis. Science 275: 1132-1136

35. Johnson LV, Walsh ML, Bockus BJ and Chen LB (1981) Monitoring of relative mitochondrial membrane potential in living cells by fluorescence microscopy. J. Cell Biol. 88: 526-535

36. Yeh JH, Hsu SC, Han SH and Lai MZ (1998) Mitogen-activated protein kinase kinase antagonized Fas-associated death domain protein-mediated apoptosis by induced FLICE-inhibitory protein expression. J. Exp. Med. 188: 1795-1802

37. Scaffidi C, Schmitz I, Krammer PH and Peter ME (1999) The role of c-FLIP in modulation of CD95-induced apoptosis. J. Biol. Chem. 274: 1541-1548

38. Komori H, Ichikawa S, Hirabashi Y and Ito M (1999) Regulation of intracellula ceramide content in B16 melanoma cells. J. Biol. Chem. 274: 8981-8987

39. Anderson RG, Vasile E, Mello RJ, Brown MS and Goldstein JL (1978) Immunocytochemical visualization of coated pits and vesicles in human fibroblasts: relation to low density lipoprotein receptor distribution. Cell 15 919-933
40. Veiga MP, Arrondo JLR, Gono FM and Alonso A (1999) Ceramides in phospholipid membranes: effects on bilayer stability and transition to nonlamellar phases. Biophys. J. 76: 342-350

41. Huang HW, Goldberg EM and Zidovetzki R (1998) Ceramides perturb the structure of phosphatidylcholine bilayers and modulate the activity of phospholipase A2. Eur. Biophys. J. 27: 361-366

42. Ito $\mathrm{M}$ and Komori $\mathrm{H}$ (1996) Homeostasis of cell-surface glycosphingolipid content in B16 melanoma cells. J. Biol. Chem. 271: 12655-12660

43. Hailstones D, Sleer LS, Parton RG and Stanley KK (1998) Regulation of caveolin and caveolae by cholesterol in MDCK cells. J. Lipid Res. 39: 369-379

44. Bist A, Fielding PE and Fielding CJ (1997) Two sterol regulatory element-like sequences mediate up-regulation of caveolin gene transcription in response to low density lipoprotein free cholesterol. Proc. Natl. Acad. Sci. 94: 10693-10698

45. Fielding PE and Fielding CJ (1995) Plasma membrane caveolae mediate the efflux of cellular free cholesterol. Biochemistry 34: 14288-14292

46. Monier S, Dietzen DJ, Hastings WR, Lublin DM and Kurzchalia TV (1996) Oligomerization of VIP21-caveolin in vitro is stabilized by long chain fatty acylation or cholesterol. FEBS Lett. 388: 143-149

47. Bijlmaker MJ and Marsh M (1999) Trafficking of an acylated cytosolic protein: newly synthesized p56(Ick) travels to the plasma membrane via the exocytic pathway. J. Cell Biol. 145: 457-468

48. Kabouridis PS, Magee Al and Ley SC (1997) S-acylation of Lck protein tyrosine kinase is essential for its signaling function in Tlymphocytes. EMBOJ. 16:49834998

49. Wolven A, Okamuro H, Rosenblatt $Y$ and Resh MD (1997) Palmitoylation of p59fyn is reversible and sufficient for plasma membrane association. Mol. Biol. Cell 8: $1159-1173$

50. Resh MD (1994) Myristoylation and palmitoylation of Src family members: the fats of the matter. Cell 76: 411-413

51. Timson-Gauen LK, Linder ME and Shaw AS (1996) Multiple features of the p59fyn src homology 4 domain define a motif for immune-receptor tyrosinebased activation motif (ITAM) binding and for plasma membrane localization. J. Cell Biol. 133: 1007-1015

52. Chung CD, Lewis LA and Micelli MC (1997) T cell antigen receptor-induced IL-2 production and apoptosis have different requirements for Lck activities. J. Immunol. 159: 1758-1766

53. Goldsmith MA and Weiss A (1988) Early signal transduction by the antigen receptor without commitment to T cell activation. Science 240: 1029-1031

54. Su B, Jacinto E, Hibi M, Kallunki T, Karin M and Ben-Neriah Y (1994) JNK is involved in signal integration during costimulation of T lymphocytes. Cell 77: $727-736$

55. Nagata S (1997) Apoptosis by death factor. Cell 88: 355-365

56. Song HY, Regnier CH, Kirschning CJ, Goeddel DV and Rothe M (1997) Tumor necrosis factor (TNF)-mediated kinase cascades: bifurcation of nuclear factorkappaB and c-jun N-terminal kinase (JNK/SAPK) pathways at TNF receptorassociated factor 2. Proc. Natl. Acad. Sci. 94: 9792-9796

57. Baker SJ and Reddy EP (1998) Modulation of life and death by the TNF receptor superfamily. Oncogene 17: $3261-3270$ 